\title{
Surface roughness of composite resins submitted to three different finish and polish
}

\section{systems}

Rugosidade superficial de resinas compostas submetidas à três diferentes sistemas de acabamento e polimento

Rugosidad superficial en resinas compuestas sometidas a tres diferentes sistemas de acabado y pulido

Lorem Krsna de Morais-Sousa

ORCID: https://orcid.org/0000-0001-7005-2867 Universidade do Estado do Rio Grande do Norte, Brazil E-mail: loremks@hotmail.com

Isabela Pinheiro Cavalcanti Lima

ORCID: https://orcid.org/0000-0002-7681-9675 Universidade do Estado do Rio Grande do Norte, Brazil E-mail:belapcl@yahoo.com.br

Francisco de Assis do Nascimento-Júnior

ORCID: https://orcid.org/0000-0001-6613-478X Universidade do Estado do Rio Grande do Norte, Brazil E-mail:assisjr16@live.com

Adrielly Fonseca Mendes

ORCID: https://orcid.org/0000-0003-1003-3669 Universidade do Estado do Rio Grande do Norte, Brazil E-mail: adriellyfonseca.enf@hotmail.com

Taynara de Araújo Ribeiro Tabosa

ORCID: https://orcid.org/0000-0003-2396-8147 Universidade do Estado do Rio Grande do Norte, Brazil E-mail: Nara.ribeiroo@ hotmail.com

\begin{abstract}
Objective: This study aimed to evaluate the in vitro performance of three different finishing and polishing systems, concerning providing better surface smoothness. Materials and methods: 2x4 mm specimens were made with 6 composites: Filtek Z250, Classic Herculite, Opalis, Filtek Z350, Zirconfilll and Estelite Omega, which were subsequently divided into four groups according to a different finishing system (Sof-Lex, OptiDisc, Praxis and Control). After polishing, twelve specimens were distributed to each of the six resins studied, making a total of 72 samples $(\mathrm{n}=$ 3 ), which had their roughness evaluated by a contact roughnessmeter. The Kruskal-Wallis test and Dunn's post-test with Bonferroni adjustment were used to search for significant differences. Values were considered significant when $\mathrm{p}<0.05$. Results: The roughness values for finishing systems showed statistical differences between OpiDisc $\mathrm{x}$ Praxis $(\mathrm{p}=1,000)$, OpiDisc and Sof-lex $(\mathrm{p}=0.605)$ and Control and all systems $(\mathrm{p}<0.0001)$. There was no statistical difference when analyzing the combination of resin x system. The Mylar strip provided surface quality. Conclusions: The size, composition and shape of the filler influenced the surface. Sof-lex and Praxis showed similar results, thus being a good choice for polishing. Clinical Relevance: This study aimed to help the professional in the choice of a better material in the polishing step.
\end{abstract}

Keywords: Dental aesthetics; Composite resins; Dental polishing; Operative dentistry.

\section{Resumo}

Objetivo: O presente estudo teve como objetivo avaliar o desempenho in vitro de três diferentes sistemas de acabamento e polimento, considerando sua capacidade de proporcionar melhor lisura. Materiais e Métodos: Espécimes de 2x4 mm foram confeccionados com 6 compósitos: Filtek Z250, Classic Herculite, Opalis, Filtek Z350, Zirconfilll e Estelite Omega, que foram posteriormente divididos em quatro grupos de acordo com um sistema de acabamento diferente (SofLex, OptiDisc, Praxis e controle). Após o polimento, doze corpos de prova foram distribuídos para cada uma das seis resinas estudadas, perfazendo um total de 72 amostras $(n=3)$, as quais tiveram sua rugosidade avaliada por um rugosímetro de contato. O teste de Kruskal-Wallis e o pós-teste de Dunn com ajuste de Bonferroni foram usados para buscar diferenças significativas. Os valores foram considerados significativos quando $\mathrm{p}<0,05$. Resultados: Os valores de rugosidade dos sistemas de acabamento apresentaram diferenças estatísticas entre OpiDisc x Praxis $(\mathrm{p}=1.000)$, OpiDisc e Sof-lex $(\mathrm{p}=0,605)$ e Controle e todos os sistemas ( $\mathrm{p}<0,0001)$. Não houve diferença estatística ao analisar a 
combinação resina x sistema. A tira de Mylar forneceu qualidade de superfície. Conclusões: O tamanho, composição e forma do filler influenciaram a superfície. Sof-lex e Praxis apresentaram resultados semelhantes, sendo, portanto, uma boa escolha para polimento. Relevância Clínica: Este estudo teve como objetivo auxiliar o profissional na escolha do melhor material na etapa de polimento.

Palavras-chave: Estética dentária; Resinas compostas; Polimento dentário; Dentística operatória.

\begin{abstract}
Resumen
Objetivo: El presente estudio tuvo como objetivo evaluar el desempeño in vitro de tres sistemas diferentes de acabado y pulido, considerando su capacidad para proveer una mejor suavidad. Materiales y Métodos: Se realizaron muestras de 2x4 mm con 6 composites: Filtek Z250, Classic Herculite, Opalis, Filtek Z350, Zirconfilll y Estelite Omega, que posteriormente se dividieron en cuatro grupos según un sistema de acabado diferente (Sof-Lex, OptiDisc, Praxis y control). Después del pulido, se distribuyeron doce muestras a cada una de las seis resinas estudiadas, haciendo un total de 72 muestras $(n=3)$, a las que se les evaluó la rugosidad mediante un rugosímetro de contacto. Se utilizaron la prueba de Kruskal-Wallis y la posprueba de Dunn con ajuste de Bonferroni para buscar diferencias significativas. Los valores se consideraron significativos cuando $\mathrm{p}<0,05$. Resultados: Los valores de rugosidad de los sistemas de acabado mostraron diferencias estadísticas entre OpiDisc x Praxis $(\mathrm{p}=1,000)$, OpiDisc y Sof-lex $(\mathrm{p}=0,605)$ y Control y todos los sistemas ( $\mathrm{p}<0,0001)$. No hubo diferencia estadística al analizar la combinación resina x sistema. La tira de Mylar proporcionó calidad de superficie. Conclusiones: El tamaño, la composición y la forma del relleno influyeron en la superficie. Sof-lex y Praxis mostraron resultados similares, siendo, por tanto, una buena opción para el pulido. Relevancia clínica: Este estudio tuvo como objetivo ayudar al profesional a elegir el mejor material en el paso de pulido. Palabras clave: Estética dental; Resinas compuestas; Pulido dental; Operatoria dental.
\end{abstract}

\title{
1. Introduction
}

Composite resin restorations require the performance of sensitive steps to obtain an ideal result (Lowe, 2015). For this reason, the evolution of composites was accompanied by the evolution of the materials that are part of these steps (Avsar, et al., 2015). Among these, the finishing and polishing stand out for its impact on the surface quality of restorations (Kocaağaoğlu, et al., 2016; St-Pierre, et al., 2019).

Similarly, the structural composition of the resin itself, the finishing and polishing step has an influence on the surface quality of the restorations (Rodrigues-Júnior, et al., 2015) through the reduction of surface roughness and irregularities, thus minimizing the accumulation of biofilm and stains caused by the penetration of solutions and pigments of dietary origin (Itanto, et al., 2017; Lassila, et al., 2020; Morais, et al., 2015; Ruivo, et al., 2019). The finishing and polishing are considered critical during the restoration stage, as it influences essential factors for the restoration, such as aesthetics, strength and durability (Kocaağaoğlu, et al., 2016; Morais, et al., 2015; Schimitt, et al., 2016).

Superficial irregularities can provide an unpleasant tactile perception to the patient. The clinically acceptable roughness value of restoration is $0.2 \mu \mathrm{m}$, which is similar to the degree of smoothness of the enamel (Itanto, et al., 2017). However, patients can perceive the roughness of restoration with the tip of the tongue. Due to tactile sensitivity, surfaces with roughness between $0.25 \mu \mathrm{m}$ and $0.5 \mu \mathrm{m}$ can be easily perceived (Alves, et al., 2015).

Some factors affect the quality of the surface of restorations, such as the quantity and size of inorganic particles, where smaller particles result in better surface smoothness (Rodrigues-Júnior, et al., 2015). Another important point is that the size difference between the matrix and the particles prevents an ideal polishing because the difference in the hardness between both causes the wear to occur in different degrees, forming craters (Schimitt, et al., 2016).

Considering that the surface roughness of a resin can be reduced from $26 \%$ to $74 \%$ through finish and polishing, a failure in this step can lead to a series of clinical problems, such as accumulation of biofilm caused by surface irregularities and superficial staining, a factor that may lead to the need to early change of restoration (Llena et al., 2016; Morais, et al., 2015). Likewise, the quality of polishing depends on factors such as the materials used, the different techniques and the operator (Itanto et al., 2017).

There is currently a wide variety of finishing and polishing systems available on the market, such as abrasive discs, diamond burs and different polishing pastes (Avsar, et al., 2015; Schimitt, et al., 2016). For the professional, the choice of which 
system to use in his practice contemplates the clinical time, the dental element involved and the composite resin of choice, since it has been proven that the finishing and polishing systems behave different way according to the resin submitted to them (Rodrigues-Júnior, et al., 2015).

Likewise, cost-benefit can influence the choice of material, between national and international brands, there is a wide variation in prices of these materials (Avsar, et al., 2015) and one must consider which of these are the best choice between price, clinical time and results (Ardur, et al., 2018). Given the importance of this step for the quality and longevity of the restoration, this choice presents itself as a crucial measure both for adequate treatment and for the cost-benefit of the professional.

Therefore, this work aims to test through an experimental study the effectiveness of some of the systems currently available on the market, with similarities in their techniques and structures, but with different manufacturers and costs, aiming to facilitate this clinical choice, considering the quality of the polishing as the surface smoothness provided.

\section{Materials and Methods}

The systems selected for the study were discs impregnated with aluminium oxide from three different manufacturers (Figure 1), for they are responsible for producing more homogeneous surfaces when compared to other systems (Avsar, et al., 2015). Also, the choice of discs with the same polishing substance helps to reduce confounding variables.

The resins chosen were three micro-hybrids and three nano-hybrids composites currently on the market and used in anterior teeth (Figure 2), areas where polishing discs are more suitable. Both have good mechanical properties combined with good aesthetics and, therefore, are materials widely used (Enone, et al., 2017), making it important to study their performance. The systems and resin composites information provided by the manufacturers are summarized in the Tables 1 and 2, respectively.

For the manufacture of the control group, the use of Mylar® strips was chosen, the material usually indicated as responsible to produce smoother surfaces (Avsar, et al., 2015; Kocaağaoğlu, et al., 2016; Schmitt, et al., 2016).

Figure 1. Finishing and polishing systems used, in order: Sof-lex Pop on (Orange series), OptiDisc $®$ and Praxis.
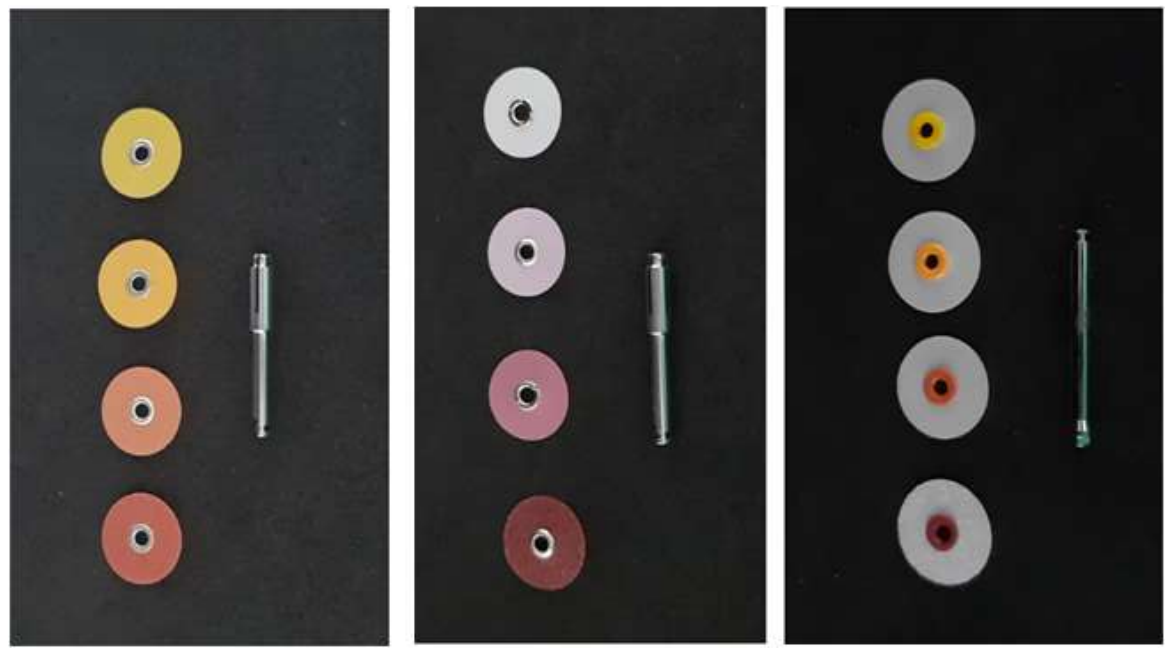

Source: Authors. 
Figure 2. Composite resins used, in order: Filtek Z250, Classic Herculite, Opalis, Filtek Z350, Zirconfill and Estelite Omega.

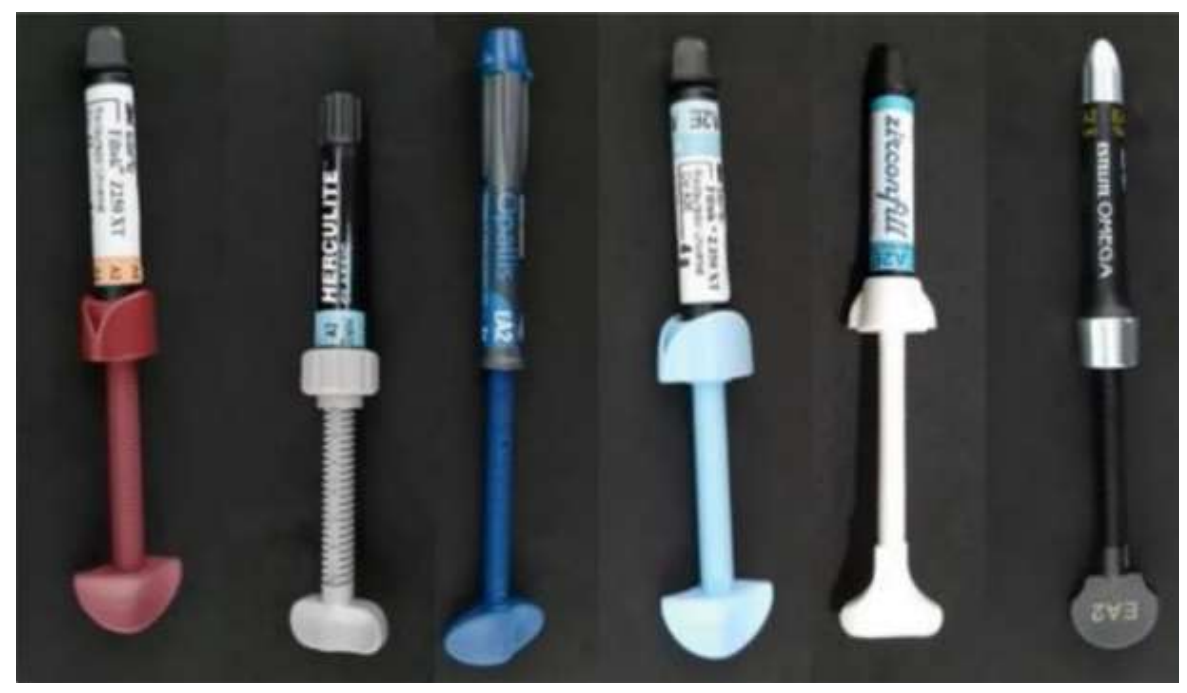

Source: Authors.

Table 1. Information on the finishing and polishing systems selected.

\begin{tabular}{|c|c|c|c|}
\hline System & Sof-lex Pop on ${ }^{\circledR}$ & OptiDisc ${ }^{\circledR}$ & $\operatorname{Praxis}{ }^{\circledR}$ \\
\hline Classification & Polyester discs & Polyester discs & Polyester discs \\
\hline Diameter & $12,77 \mathrm{~mm}$ & $12,6 \mathrm{~mm}$ & $12 \mathrm{~mm}$ \\
\hline Abrasive particles & Aluminum Oxide & Aluminum Oxide & Aluminum Oxide \\
\hline Granulation $(\mu \mathrm{m})$ & $\begin{array}{l}\text { Coarse - } 55 \mu \mathrm{m} \\
\text { Medium- } 40 \mu \mathrm{m} \\
\text { Fine - } 24 \mu \mathrm{m} \\
\text { Superfine - } 8 \mu \mathrm{m}\end{array}$ & $\begin{array}{c}\text { Extra Coarse }-80 \mu \mathrm{m} \\
\text { Coarse/Medium - } 40 \\
\mu \mathrm{m} \\
\text { Fine }-20 \mu \mathrm{m} \\
\text { Superfine }-10 \mu \mathrm{m}\end{array}$ & $\begin{array}{c}\text { Coarse }-103 \mu \mathrm{m} \\
\text { Medium }-53 \mu \mathrm{m} \\
\text { Fine }-24 \mu \mathrm{m} \\
\text { Ultrafine }-18 \mu \mathrm{m}\end{array}$ \\
\hline Batch number & 1825700622 & 199204 & 1083753101 \\
\hline Manufacturer & $3 \mathrm{M} \mathrm{ESPE}^{\mathrm{TM}}$ & Kerr Dental $^{\mathrm{TM}}$ & TDV Dental Ltda. \\
\hline
\end{tabular}

Source: Authors. 
Table 2. Informations about the composites selected.

\begin{tabular}{|c|c|c|c|c|c|c|}
\hline Composite & Filtek $®$ Z250 XT & $\begin{array}{l}\text { Herculite } \\
\text { clássico }\end{array}$ & Opalis & Filtek ${ }^{\circledR}$ Z350 XT & Zirconfill@ & $\begin{array}{l}\text { Estelite } \\
\text { Omega }\end{array}$ \\
\hline Classification & Microhybrid & Microhybrid & Microhybrid & Nanohybrid & Nanohybrid & Nanohybrid \\
\hline $\begin{array}{l}\text { Inorganic filler } \\
\text { particle size }\end{array}$ & $\begin{array}{c}0.01 \mu \mathrm{m} \text { at } 3.5 \\
\mu \mathrm{m} \text { with } \\
\text { average size of } 0.6 \mu \mathrm{m}\end{array}$ & $\begin{array}{c}\text { Average of } 0.6 \\
\mu \mathrm{m}\end{array}$ & $\begin{array}{c}\text { Average size of } \\
0.5 \mu \mathrm{m}\end{array}$ & $\begin{array}{c}4-11 \mathrm{~nm} \\
20 \mathrm{~nm} \\
0.6-10 \mu \mathrm{m} \\
0.6-20 \mu \mathrm{m}\end{array}$ & $\begin{array}{c}20 \mathrm{~nm} \\
15.8 \mu \mathrm{m}\end{array}$ & $\begin{array}{c}100 \text { a } 300 \mathrm{~nm} \\
\text { Average size } \\
200 \mathrm{~nm}\end{array}$ \\
\hline $\begin{array}{l}\text { Polymeric } \\
\text { matrix }\end{array}$ & $\begin{array}{l}\text { BIS- GMA }{ }^{1} \\
\text { BIS - EMA }{ }^{2} \\
\text { UDMA }\end{array}$ & $\begin{array}{l}\text { BIS-GMA } \\
\text { TEGDMA }^{3}\end{array}$ & $\begin{array}{c}\text { BIS-GMA } \\
\text { BIS-EMA } \\
\text { TEGDMA } \\
\text { UDMA }^{4}\end{array}$ & $\begin{array}{c}\text { BIS-GMA } \\
\text { UDMA } \\
\text { TEGDMA } \\
\text { BIS-EMA }\end{array}$ & $\begin{array}{c}\text { BIS-GMA } \\
\text { UDMA } \\
\text { TEGDMA } \\
\text { BIS-EMA }\end{array}$ & $\begin{array}{l}\text { BIS-GMA } \\
\text { TEGDMA } \\
\text { MEQUINOL }\end{array}$ \\
\hline Colour & $\mathrm{A} 2 \mathrm{E}$ & $\mathrm{A} 2 \mathrm{E}$ & $\mathrm{A} 2 \mathrm{E}$ & $\mathrm{A} 2 \mathrm{E}$ & $\mathrm{A} 2 \mathrm{E}$ & $\mathrm{A} 2 \mathrm{E}$ \\
\hline $\begin{array}{l}\text { Batch number } \\
\text { Manufacturer }\end{array}$ & $\begin{array}{l}1818700420 \\
3 \mathrm{M} \text { ESPE }{ }^{\circledR}\end{array}$ & $\begin{array}{l}6212002 \\
\text { Kerr }{ }^{\circledR}\end{array}$ & $\begin{array}{l}270213 \\
\text { FGM® }\end{array}$ & $\begin{array}{l}1818600624 \\
3 \mathrm{M} \text { ESPE }\end{array}$ & $\begin{array}{l}18038 \\
\text { BM4® }\end{array}$ & $\begin{array}{c}\text { 101EY7 } \\
\text { Tokuyama }{ }^{\circledR}\end{array}$ \\
\hline
\end{tabular}

Abbreviations: ${ }^{1}$ Bis-GMA: bisphenol A diglycidyl methacrylate; ${ }^{2}$ Bis-EMA: bisphenol A diglycidyl methacrylate ethoxylated; ${ }^{3}$ TEGDMA: triethylene glycol dimethacrylate, ${ }^{4}$ UDMA: urethane dimethacrylate. Source: Authors.

To make the specimens, it was manufactured square transparent acrylic plates $2 \mathrm{~mm}$ thick, $7 \mathrm{~cm}$ high and $7 \mathrm{~cm}$ wide. The design of this plat was created by the author for use in this study, aiming a matrix that should stabilize the samples during the creation and the tests that would be realized along the study. Each plate carried 4 holes of $4 \mathrm{~mm}$ in diameter with $4 \mathrm{~cm}$ of distance between them and $1 \mathrm{~cm}$ of distance between the holes and the edge of the plate (Figure 3). Eighteen structures were used in this study, making a total of 72 cylindrical specimens with $4 \mathrm{~mm}$ in diameter and $2 \mathrm{~mm}$ in thickness.

For the creation of the specimens, the structure was positioned on a glass plate with a polished surface (FAVA) and the resin was inserted in a single increment inside each hole (Figure 4) with the help of a titanium-coated spatula (Thompsonß). Then, a polyester strip (MylarTM) was placed on top of the resin, and on top of it, a glass slide was placed with light pressure, aiming at the removal of excess resin, and also serving as a standardization of the distance from the tip of the light-curing device (Figure 5). This protocol as chosen as provided by literature (Avsar, et al., 2015; Kocaağaoğlu, et al., 2016; Schmitt, et al., 2016). The photoactivation was carried out according to the time indicated by the manufacturer of each resin, using light-curing (Optilight Max, Saevo, GNATUS) with a power intensity of $1200 \mathrm{~mW} / \mathrm{cm} 2$.

After, the plates were fixed to a flat surface parallel to the ground. A contra-angle and a micro-motor (Kavo Kerr) were used to perform the polishing procedure. Except for the control group, the specimens were polished (Figure 6), according to the manufacturers' instructions, in a single direction, with intermittent movements and performed by the same operator. Water spray was used for five seconds after each polishing to remove debris.

After the procedure, the samples were catalogued and immersed in distilled water and kept in an incubator with a temperature of $37^{\circ} \mathrm{C}$ for a period of 24 hours. After that period, the groups were distributed.

Twelve specimens were distributed to each of the six studied resins $(n=3)$, three specimens of each resin were subjected to each of the polishing systems and the remaining three became the control group, which remained unpolished.

After the distribution of the samples in their groups, the evaluation of the surface roughness was performed. A Mitutoyo SJ-411 contact rugosimeter was used for this procedure. 
The readings were taken at three different points on the surface in a vertical pen movement, with a cutoff value of 0.2 $\mathrm{mm}$ per second and speed of $0.25 \mathrm{~mm}$ per second. Three successive measurements were made on each sample, obtaining an average value.

Data analysis was performed using SPSS version 22, with descriptive data analysis based on frequencies, media, medians and quartiles. Assuming the non-normality and the independence of the sample, the Kruskal-Wallis test and Dunn's post-test with Bonferroni adjustment were used, to search for significant differences. Values were considered significant when $\mathrm{p}<0.05$.

Figure 3. Plate used for manufacturing the samples.

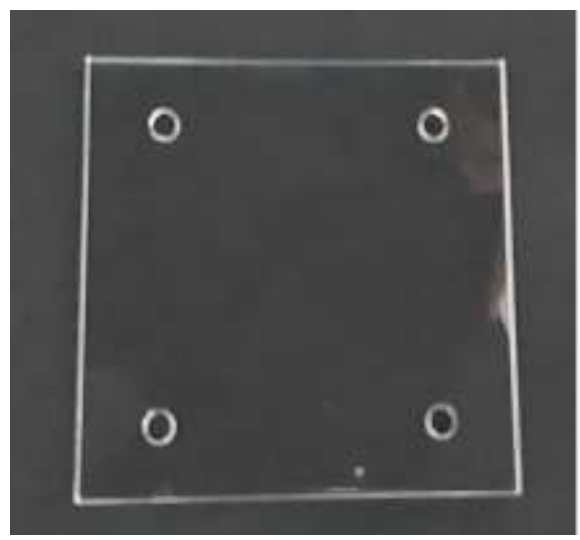

Source: Authors.

Figure 5. Set of polyester strip and glass slide.

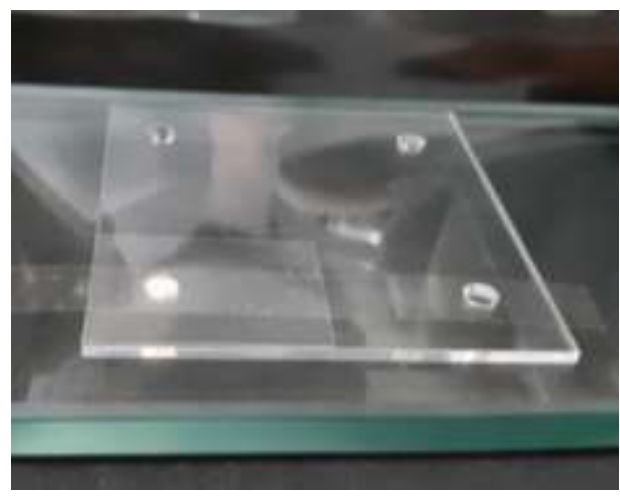

Source: Authors.
Figure 4. Increment inserted.

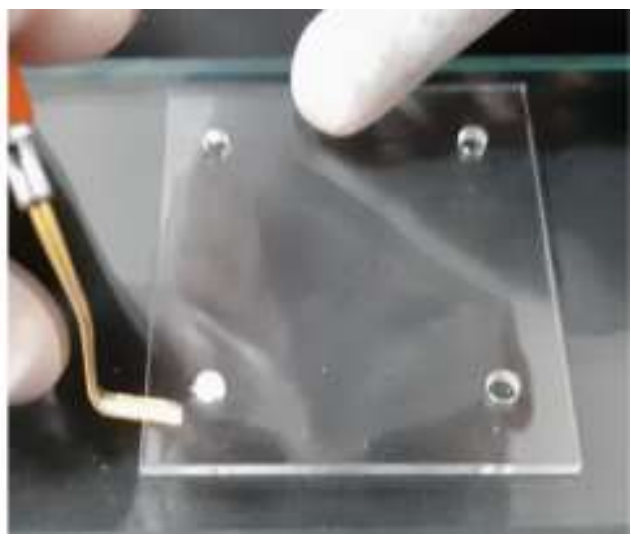

Source: Authors.

Figure 6. Polishing.

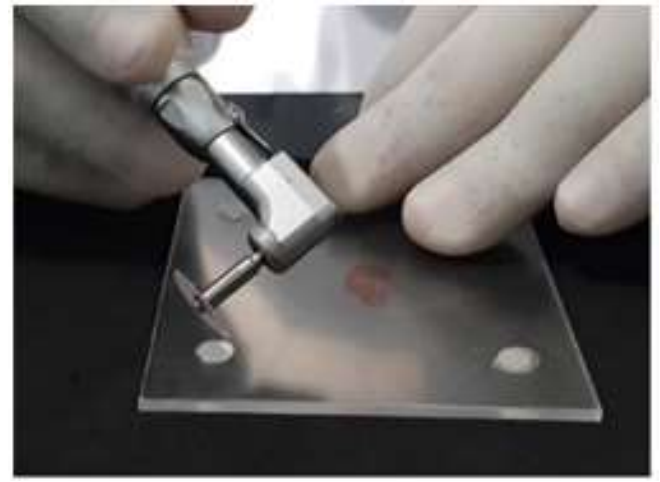

Source: Authors.

\section{Results}

The Ra mean was 0.427 (SD / Standard Deviation = 0.248). Comparing the resins according to the Ra no significance was observed, however when comparing the roughness according to the system, as is showed in Table 3, OptiDisc presented the highest roughness and this difference was significant.

The systems were assessed separately in search of which composite presented the smoothest surface for which system. For OptDisk $(\mathrm{p}=0.083)$, Praxis $(\mathrm{p}=0.232)$ and Sof-lex $(\mathrm{p}=0.055)$ there was no significant difference between resins when Ra was evaluated, as is showed in Figure 7. 
Table 3. Date for Ra results for the composites and systems, presented as median and minimum - maximum range.

\begin{tabular}{|c|c|c|c|c|}
\hline \multirow{2}{*}{$\begin{array}{c}\text { Resin } \\
\text { Composites }\end{array}$} & \multicolumn{4}{|c|}{ Finishing and Polishing Systems } \\
\hline & OptiDisc & Praxis & Sof-lex & Control \\
\hline Z350 XT & $0.86(0.66-0.87) b$ & $0.41(0.36-0.57)$ & $0.38(0.37-0.38)$ & $0.09(0.03-0.13)$ \\
\hline Herculite Classic & $0.59(0.32-0.70)$ & $0.59(0.32-0.72)$ & $0.41(0.29-0.53)$ & $0.04(0.03-0.2)$ \\
\hline Opalis & $0.52(0.18-0.65)$ & $0.5(0.36-0.52)$ & $0.59(0.43-0.86)$ & $0.09(0.08-0.72)$ \\
\hline Zirconfill & $0.49(0.36-0.50)$ & $0.43(0.33-0.48)$ & $0.28(0.28-0.28)$ & $0.14(0.13-0.28)$ \\
\hline $\mathbf{Z 2 5 0}$ & $0.47(0.33-0.69)$ & $0.54(0.15-0.66)$ & $0.23(0.19-0.37)$ & $0.27(0.23-0.30)$ \\
\hline Estelite Omega & $0.29(0.16-0.43)$ & $0.26(0.14-0.45)$ & $0.41(0.24-0.64)$ & $0.35(0.26-0.36)$ \\
\hline
\end{tabular}

$\mathrm{a}=$ difference in relation to finishing systems; $\mathrm{b}=$ difference in relation to resin; $\mathrm{c}=$ difference in relation to resin $\mathrm{x}$ system combination / OpiDisc $\mathrm{x}$ Praxis $=$ 1,000; OpiDisk x Sof-lex $=0,605$; Control x all p<0,0001. Source: Authors.

Figure 7. Graph 1. Interaction plot graph for the results of the surface roughness of each system related to the different resins. Resins composite: 1- Z350; 2- Herculite; 3-Opallis; 4- Zirconfill; 5- Z250; 6- Estelite Omega. Finishing Systems: 1- OptiDisc; 2- Praxis; 3- Sof-lex; 4-Control.

Interaction Plot

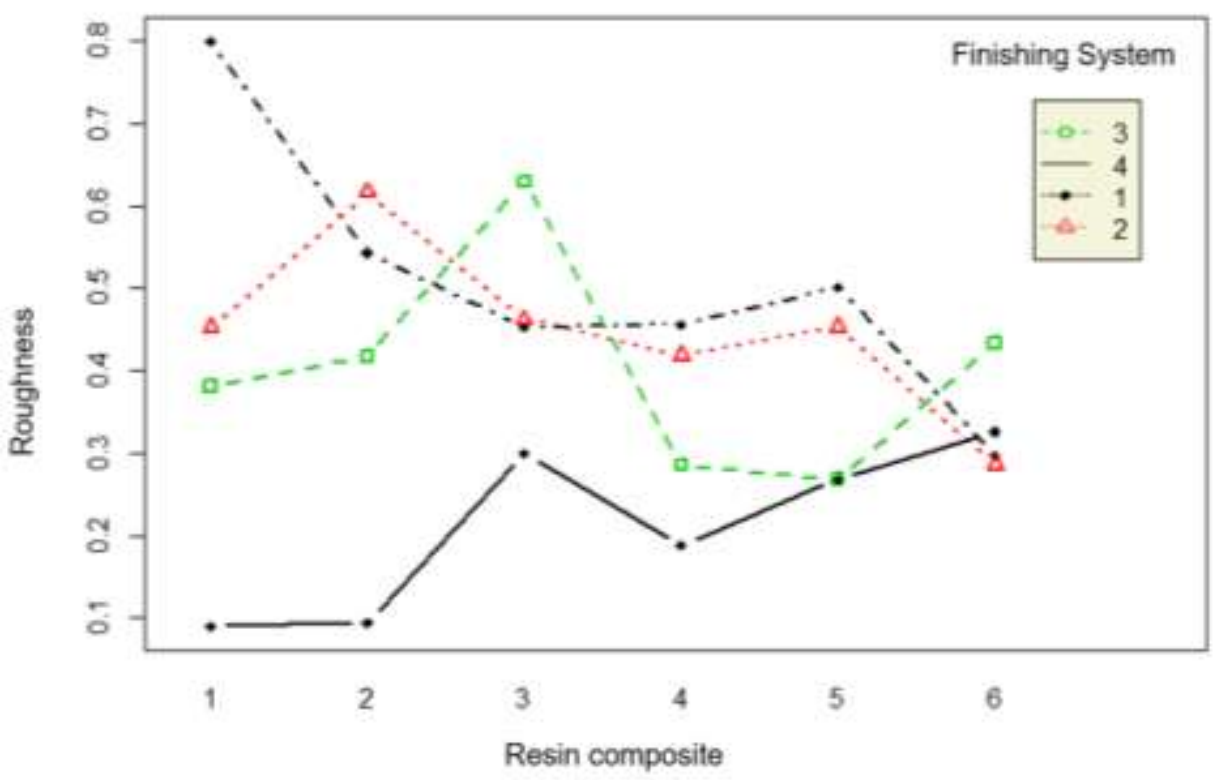

Source: Authors.

\section{Discussion}

The replacement of deficient composite restorations represents a negative impact on the remaining dental structure and financial loss to the patient and /or professional (Avsar, et al., 2015). The surface quality influences the longevity of resin restorations (Tavangar, et al., 2018)., by affecting its resistance to wear and discolouration, one of the most pointed factors as the cause of replacement for aesthetic dissatisfaction (Ardur, et al., 2018; Morais, et al., 2015).

The use of Mylar strips under a restoration before photopolymerization was indicated as responsible to produce the smoothest surfaces (Avsar, et al., 2015; Bansal, et al., 2019; Schimitt, et al., 2016), a result also found in the present study. 
However, the clinical use of this technique is not effective, mainly due to the need to remove the resin-rich surface layer (Mathias, et al., 2015) which makes polishing indispensable.

Regarding roughness, between the systems, there were statistical differences between the OptiDisc x Praxis and OptiDisc x Sof-lex system, with the OptiDisc system providing a rougher surface than the others, while the Sof-lex showed the best results.

The success of Sof-lex discs was attributed mainly to the malleability of the discs, which, because they do not cause load displacement, promote a more homogeneous abrasion (Alves, et al., 2015). Also, the size of its abrasive particles causes the removal of the residual matrix without displacing the glass (Avsar, et al., 2015). Praxis discs, like Sof-lex, have more malleable structures than those of OptDisc, which can also be associated with their results.

The systems depend on the resins submitted to them (Rodrigues-Júnior, et al., 2015), this means that the systems will behave differently depending on the composition of the studied resins, a fact that was also observed in this study. Particularly, resins showed better results in systems from the same manufacturer, a fact previously observed in other studies (Abzal, et al., 2016; Patel, et al., 2016).

Concerning the evaluated resins, no statistical differences were observed between them, however, a better surface quality was observed in the nanohybrid resins when compared to microhybrids. This can be associated with differences in the size of the filler particles, as nanoparticles reduce the interstitial space between the filler particles, leading to a smoother surface (Schimitt, et al., 2016).

The shape and type of the fillers can also be associated with polishing, since the resins that showed the best surface smoothness have differentiation in them. Estelite Omega has spherical and monodispersed supra-nano particles, which due to its geometry allows a more uniform polishing. The same can be said about the Z250 resin, which also has the same spherical filler particle, and it was among the microhybrid resins that presented the best surface smoothness. The Zirconfill composite also has the addition of diatomite in its composition, which among other mechanical improvements (Feitosa, 2018) has also been observed to provide better polishing capacity (Lima, 2005).

The Estelite Omega + OptiDisc provided the smoothest surface between the combinations (0.196) while Z350XT + OptiDisc (0.878) presented the roughest surface, however, these results did not show statistical significance.

The main limitation of the study was that the specimen surfaces were flat, whereas restorations presented an irregular shape. Also, the polishing procedure as was performed may be difficult to repeat clinically. Protocols of how to reduce this variable may be considered in further studies.

\section{Conclusions}

It was observed that polishing is involved with the size, shape and compositions of the filler particles. Composites with spherical particles showed better surface smoothness.

Among the systems, it is important to note that although the Sof-lex system presents the best results, Praxis showed similar results, thus when considering the cost-benefit for the clinician this system presents as a good alternative of choice.

Considering the variables of this study on the use of flat surfaces, that differ of the irregular shape of restorations, it is important to consider further similar studies of those systems with protocols that can reduce this variable.

\section{Compliance with ethical standard}

Conflict of Interest: The authors declares that has no conflict of interest. 


\section{Funding}

The work was supported by the authors personal fundigs.

\section{Ethical approval}

This article does not contain any studies with human participants or animals performed by any of the authors.

\section{Informed consent}

For this type of study, formal consent is not required.

\section{References}

Abzal, M. S., \& Rathakrishnan, M., \& Prakash, V., \& Vivekanandhan, P., \& Subbiya, A., \& Sukumaran, V. G (2016). Evaluation of surface roughness of three different composite resins with three different polishing systems. J Conserv Dent, 19 (2), 171-174

Alves, C. B., \& Giuriato, J. B., \& Turbino, M. L., \& Oda, M (2015). Rugosidade superficial de diferentes resinas compostas comparando sistemas de acabamento e polimento e após a profilaxia com jato de bicarbonato - Estudo in vitro. Clinical and Laboratorial Research in Dentistry, 21 (1), $11-17$.

Ardu, S., \&Duc,O., \&Bella, E.D., \& Krejci, I (2018). Color stability of different composite resins after polishing. Odontology, 106 (3), $328-333$.

Avsar, A., \& Yuzbasioglu, E., \& Sarac, D. (2015). The Effect of Finishing and Polishing Techniques on the Surface Roughness and the Color of Nanocomposite Resin Restorative Materials. Advances in Clinical and Experimental Medicine, 24 (5), 881-890.

Bansal, K., \& Gupta, S., \& Nikhil, V., \& Jaiswal, S., \& Jain, S., \& Aggarwal,N (2019). Effect of different finishing and polishing systems on the surface roughness of resin composite and enamel: An In vitro profilometric and scanning electron microscopy study. International Journal Of Applied And Basic Medical Research, 9 (3), 154-158.

Enone, L., \& Ilemobade,A., \& Awotile, A., \& Agbaje, L., \& Loto, A., \& Afolabi, O (2017). Comparison of the clinical performance of a nanohybrid and a microhybrid resin composite in the restoration of posterior teeth in Nigerians. Odonto-stomatologie tropicale $=$ Tropical dental journal, $40,48-58$.

Feitosa, J.L (2018). Rugosidade superficial e resistência à flexão de compósitos restauradores diretos fotoativados por diodo emissor de luz (LED). Dissertation, Mossoró, Universidade do Estado do Rio Grande do Norte.

Itanto, B.S.H., \& Usman, M., \& Margono, A (2017). Comparison of surface roughness of nanofilled and nanohybrid composite resins after polishing with a multi-step technique. Journal Of Physics: Conference Series, 884, 1-7.

Kocaağaoğlu, H., \& Aslan, T., \& Gürbulak, A., \& Albayrak, H., \& Taşdemir, Z., \& Gumus, H. (2016). Efficacy of polishing kits on the surface roughness and color stability of different composite resins. Nigerian Journal of Clinical Practice 20 (5), 557-565.

Lassila, L., \& Säilynoja, E., \& Prinssi, R., \& Vallittu, P.K., \& Garoushi, S (2020). The effect of polishing protocol on surface gloss of different restorative resin composites. Biomaterial Investigations In Dentistry, 7 (1), 1-8.

Lima, I. P. C (2005). Caracterização e avaliação do incremento de diatomita em uma resina comercial de uso odontológico. Dissertation, Natal, Universidade Federal do Rio Grande do Norte.

Llena, C., \& Fernández, S., \& Forner, L (2016). Color stability of nanohybrid resin-based composites, ormocers and compomers. Clinical Oral Investigations, $21(4), 1071-1077$.

Lowe R (2015). Advances in Composite Resin Materials: The material science behind modern restoratives. Inside Dentistry, 11 (10), 1-7.

Mathias, P., \&, Silva, E. V. F., \& Vitória, L. A., \& Azevedo, J. F (2015). Pigmentação de restaurações de resina composta: Uma revisão de literatura. Revista Odontológica de Araçatuba, 36 (2), 29-35.

Morais, R. C. D., \& Garcia, L. D. F. R., \& Cruvinel, D. R., \& Pires-De-Souza, F. D. C. P (2015). Color stability and surface roughness of composite submitted to different types and periods of finishing/polishing: physical properties of composites. The Journal of Contemporary Dental Practice, 16 (7), 666-670.

Patel, B.., \& Chhabra, N., \& Jain, D (2016). Effect of different polishing systems on the surface roughness of nano-hybrid composites. J Conserv Dent, 19 (1), $37-40$.

Rodrigues-Junior, S. A., \& Chemin, P., \& Piaia, P. P., \& Ferracane, J. L. (2015). Surface roughness and gloss of actual composites as polished with different polishing systems. Oper Dent 40 (4), 418-29.

Ruivo, M. A., \& Pacheco, R.R., \& Selbod, M., \& Gianinni, N (2019). Surface roughness and filler particles characterization of resin- based composites. Microscopy Research And Technique, 82 (10), 1756-1767.

Schmitt, V. L. \& Nahsan, F. P. S., \& Naufel, F. S., \& Vaez, S. C., \& Andrade, G. S. D., \& Baseggio, W., \& Sinhoreti, M. A. C., \& Puppin-Rontani, R. M (2016). Polishing techniques effect on microhybrid, nanohybrid and nanofilled composites color and surface roughness stability. Biosci. J, 32(1), 262-271. 
St-Pierre, L., \& Martel, C., \& Crépeau, H., \& Vargas (2019). Influence of Polishing Systems on Surface Roughness of Composite Resins: Polishability of Composite Resins. Operative Dentistry 44 (3), 122-132.

Tavangar, M., \& Bagheri, R., \& Kwon, T., \& Mese, A., \& Manton, D.J (2018). Influence of beverages and surface roughness on the color change of resin composites. Journal Of Investigative And Clinical Dentistry, 9 (3), 1-8. 